\title{
Chemical and isotopic study of thermal springs and gas discharges from Sierra de Chiapas, Mexico
}

\author{
A. Nencetti ${ }^{1}$, F. Tassi ${ }^{1}$, O. Vaselli ${ }^{1,2}$, J. L. Macías ${ }^{3}$, G. Magro ${ }^{4}$, B. Capaccioni ${ }^{5}$, A. Minissale ${ }^{2}$ and J.C. Mora ${ }^{3}$ \\ ${ }^{1}$ Department of Earth Sciences, Florence, Italy \\ ${ }^{2}$ CNR-Institute of Geosciences and Earth Resources, Florence, Italy \\ ${ }^{3}$ Institute of Geophysics, UNAM, Mexico D.F, Mexico \\ ${ }^{4}$ CNR-Institute of Geosciences and Earth Resources, Pisa, Italy \\ ${ }^{5}$ Institute of Volcanology and Geochemistry, Urbino, Italy
}

Received: January 23, 2003; accepted: October 19, 2004

\section{RESUMEN}

La Sierra de Chiapas localizada en el Sureste de México, se caracteriza por la presencia de descargas de gas y agua. La mayoría de los manantiales termales se asocian a rocas volcánicas Terciarias a lo largo de fallas regionales con orientación NOSE.

Las descargas termales se dividen en cuatro grupos: i) aguas con composición Na-Cl y Sólidos Disueltos Totales (SDT) $>3000 \mathrm{mg} / \mathrm{L}$; ii) aguas con composición Ca-SO y valores de SDT entre 1400 y $2300 \mathrm{mg} / \mathrm{L}$; iii) aguas con composición Na-Cl, bajos contenidos de SDT (800 $2400 \mathrm{mg} / \mathrm{L}$ ) y un contenido de sulfato alto (hasta $650 \mathrm{mg} / \mathrm{L}$ ) y iv) aguas con una composición Ca$\mathrm{HCO}_{3}$ y salinidad baja (SDT $<250 \mathrm{mg} / \mathrm{L}$ ). La mayoría de estas aguas están asociadas con descargas de gas compuestas por $\mathrm{N}_{2}$ (hasta $93 \%$ en vol.), $\mathrm{CO}_{2}$ (2.4-31.2\% en vol.) y $\mathrm{Ar}$ (hasta $1.25 \%$ en vol.) con origen predominantemente meteórico. $\mathrm{H}_{2} \mathrm{~S}$ aparece únicamente en las muestras de gas colectadas en El Azufre (hasta $1.1 \%$ en vol.). Los valores de $\delta^{13} \mathrm{C}_{-} \mathrm{CO}_{2}$ comúnmente inferiores a $-9.7 \%$ (PDB) sugieren un origen parcialmente biogénico del $\mathrm{CO}_{2}$.

Los parámetros químicos e isotópicos de los manantiales indican que la circulación de fluidos en la Sierra de Chiapas se regula principalmente por la infiltración de aguas meteóricas en rocas carbonatadas del Cretácico medio-tardío hasta las formaciones evaporíticas del Jurásico tardío-Cretácico temprano. Estas últimas representan la fuente principal de las especies en solución de las aguas.

No se encontraron evidencias de la presencia de sistemas con entalpías medias a altas por debajo de la Sierra de Chiapas.

PALABRAS CLAVE: Isótopos, química de manantiales, Chiapas, México.

\begin{abstract}
Thermal water and gas discharges south-east of El Chichón volcano, Mexico are associated mainly with NW-SE oriented fault systems. Spring discharges include i) waters with $\mathrm{Na}-\mathrm{Cl}$ composition and TDS $>3000 \mathrm{mg} / \mathrm{L}$; ii) waters with Ca-SO $\mathrm{Compo-}_{4}$ sition and TDS values between 1400 and $2300 \mathrm{mg} / \mathrm{L}$; iii) waters with Na-Cl composition and TDS of 800 to $2400 \mathrm{mg} / \mathrm{L}$ and sulphate content up to $650 \mathrm{mg} / \mathrm{L}$ and iv) waters with $\mathrm{Ca}-\mathrm{HCO}_{3}$ composition and low salinity (TDS <250mg/L). Most of these waters are associated with free-gas discharges of $\mathrm{N}_{2}$ (up to $93 \%$ by vol.), $\mathrm{CO}_{2}$ ( 2.4 to $31.2 \%$ by vol.) and $\mathrm{Ar}$ (up to $1.25 \%$ by vol.) with a predominant meteoric origin. $\mathrm{H}_{2} \mathrm{~S}$ is present only in gas samples collected at El Azufre (up to $1.1 \%$ by vol.). $\mathrm{The}^{13} \mathrm{C} \mathrm{CO}_{2}$ values are always below $-9.7 \%$ (PDB) and suggest a partially biogenic origin for $\mathrm{CO}_{2}$.

Chemical and isotopic features of spring discharges indicate that fluid circulation in the Sierra de Chiapas is mainly regulated by meteoric waters that tend to infiltrate the upper and middle-Cretaceous carbonate units up to the lower Cretaceous-upper Jurassic evaporitic formations (by López-Ramos, 1982). The latter provide the main source of the species in solution.

No evidence for high-to-medium enthalpy systems at depth beneath the Sierra de Chiapas has been found.
\end{abstract}

KEY WORDS: Isotopes, chemistry, thermal springs, water, Chiapas, Mexico.

\section{INTRODUCTION}

The Sierra de Chiapas is a NW-SE elongated area transected by regional faults (Meneses Rocha, 1991; GarcíaPalomo et al., 2004). It is located in the northern-central part of Chiapas State (Southeastern Mexico), where thermal water and gas discharges occur (Figure 1). They are often used as spas and for therapeutic purposes. Despite the economic interest of these manifestations, their chemical characteriza- tion and origin are still poorly constrained. On the other hand, the thermal discharges located in the area of El Chichón volcano, after the violent eruption occurred on March 1982, have been extensively investigated (e.g. Taran et al., 1998; Tassi et al., 2003; Capaccioni et al., 2004; Rouwet et al., 2004).

This work presents the results of chemical and isotopic analyses of water samples of 9 thermal springs and 5 cold springs and gas discharges collected in November 1999. The 
sites are located in a region that includes the cities of Pichucalco, San Cristobal de Las Casas, Venustiano Carranza and Tuxtla Gutiérrez in the Chiapanecan Volcanic Arc (CVA), where several Cenozoic volcanoes occur (Figure 1). The main goals of this paper are to: i) establish the origin of thermal spring discharges; ii) determine the chemical processes governing the composition and circulation of these fluids and iii) assess their possible relations with Cenozoic volcanism in the area.

\section{TECTONICS AND GEOLOGICAL SETTING}

The Sierra de Chiapas is a folded and faulted chain of Mesozoic and Tertiary sedimentary rocks located in the central and northern portions of Chiapas State (Figure 1). The fold axes trend north-west and generally plunge north-westwards beneath the Pliocene and younger sediments of the coastal Tabasco plain of the Gulf of Mexico, as observed in the northern part of El Chichón volcano (Duffield et al., 1984; Macías et al., 1997; García-Palomo et al., 2004). Nixon (1982) proposed that an extensional tectonic regime was acting in the area probably related to the presence of a triple junction between the North American, Caribbean and Cocos plates. However, it is widely accepted that the volcanism in the region is related to the subduction of the Cocos plate beneath Mexico and Central America (Havskov et al. 1983; Burbach et al. 1984; Luhr et al., 1984; Macías et al., 2003). According to Damon and Montesinos (1978), El Chichón is the youngest volcano in the north-western part of the 150 km long CVA, a NW-SE volcanic belt within the Chiapas State. Capaul (1987) described the CVA as a Quaternary chain composed of low profile, small volume volcanoes (3 to 4 $\mathrm{km}^{3}$ ) that have erupted alkali-and-incompatible-rich andesitic rocks with respect to the Trans-Mexican Volcanic Belt and the Central America Volcanic Arc rocks.

The stratigraphic sequence of the sedimentary formations consists of: i) lower Cretaceous upper Jurassic evaporitic formations, which have locally formed salt diapirs, as resulted from drillings for petroleum explorations; ii) middle to upper Cretaceous formations of massive dolomite limestone; iii) Tertiary rocks that include Paleocene to Miocene formations, consisting predominantly of interbedded sandstones and siltstones (López-Ramos, 1979; De la Rosa et al., 1989; Ferrusquia-Villafranca, 1996; and references therein, Figure 1).

With the exception of El Chichón volcano and Los Tuxtlas Volcanic Field, a gap in the distribution of the Holocene volcanoes extends $650 \mathrm{~km}$ from Tacaná, close to the Guatemala border, to Pico de Orizaba, at the eastern end of the Trans-Mexican Volcanic Belt. Differently, a large number of Cenozoic igneous rocks are present in Chiapas, pertaining to the CVA, and the Chiapas Massif (Damon and
Montesinos, 1978). The former is mainly composed by: i) the Santa Fe mining district-Selva Negra region, dated 2.79 $\mathrm{Ma}$, consisting of volcanic and intrusive rocks and ii) the Cerro Tzontehuitz (2.14 Ma), a >3000 m high volcano close to San Cristobal de Las Casas; iii) the Cerro Lanza (0.85 Ma), a volcanic plug near Nicolás Ruíz characterized by conspicuous vertical banding and the appearance of a Peléan spine, iv) the Navenchauc volcano $(0.43 \mathrm{Ma})$ west of San Cristobal de Las Casas, and the northernmost active Chichón volcano (0.21 Ma) (Damon and Montesinos, 1978). The Chiapas Massif consists of two intrusive belts: 1) a Miocene belt (15-29 Ma) composed of granodiorites, qz-monzonites, and tonalities, parallel to the Pacific coast to the vicinity of Motozintla village and 2) a Paleozoic belt composed of granite to granodiorite rocks, parallel and inland with respect to the Miocene batholit (Mugica, 1987) (Figure 1).

\section{SAMPLING AND ANALITICAL TECHNIQUES}

All the water and gas discharges are located in proximity of the Cenozoic volcanic rocks belonging to the CVA (Figure 1). Temperature was measured with a $\mathrm{H} / \mathrm{g}$ thermometer, $\mathrm{pH}$ and $\mathrm{HCO}_{3}^{-}$by titration with $\mathrm{HCl}$, and $\mathrm{NH}_{4}^{+}$with the Nessler method. The $\mathrm{SiO}_{2}$ contents in the water samples have been measured in the field (heteropoly blue method), whereas the remaining major and trace components were analyzed in the laboratory.

Gas samples, emerging as gentle small bubbles within thermal pools, were sampled using a plastic funnel up-sidedown positioned and stored into two pre-evacuated $100 \mathrm{cc}$ thorion tapped tubes, one containing $20 \mathrm{ml}$ of a $4 \mathrm{M} \mathrm{NaOH}$ solution (Giggenbach, 1975) to concentrate the non-reactive gas compounds in the head-space of the tubes. Gas chromatographic analyses for $\mathrm{CO}_{2}, \mathrm{H}_{2} \mathrm{~S}, \mathrm{~N}_{2}, \mathrm{H}_{2}, \mathrm{He}, \mathrm{O}_{2}, \mathrm{Ar}$ and Ne contents were measured by a Shimadzu 15A gas-chromatograph equipped with a TCD (Thermal Conductivity Detector), while $\mathrm{CO}$, after its conversion to $\mathrm{CH}_{4}$ at $400^{\circ} \mathrm{C}$, and hydrocarbon compounds were analyzed with a Shimadzu 14A gas-chromatograph equipped with a FID (Flame Ionization Detector). Analytical precision was $<1 \%$ for major components and $<5 \%$ for minor and trace compounds.

$\delta^{18} \mathrm{O}$ and $\delta^{2} \mathrm{H}$ values in liquid phase were determined with a Finningan 250 Delta mass spectrometer after equilibrating the waters with $\mathrm{CO}_{2}$ and after the reaction of $10 \mu$ of water with $0.3 \mathrm{~g}$ of pure $\mathrm{Zn}$ at $500^{\circ} \mathrm{C}$, respectively. The analytical errors were $<10 \%$ for the abundance of elements and a precision of \pm 0.15 and $\pm 1.1 \%$ for oxygen and hydrogen isotopes, respectively. The ${ }^{13} \mathrm{C} /{ }^{12} \mathrm{C}$ ratios of $\mathrm{CO}_{2}$, in the gas phases, were determined using a Finningan 250 Delta mass spectrometer. Several internationally accepted standards were used, with an error of $\pm 0.05 \%$ (PDB). ${ }^{3} \mathrm{He} /{ }^{4} \mathrm{He}$ (expressed as $\mathrm{R} / \mathrm{Ra}$, where $\mathrm{R}$ is the measured ratio and $\mathrm{Ra}$ is that in the air, 


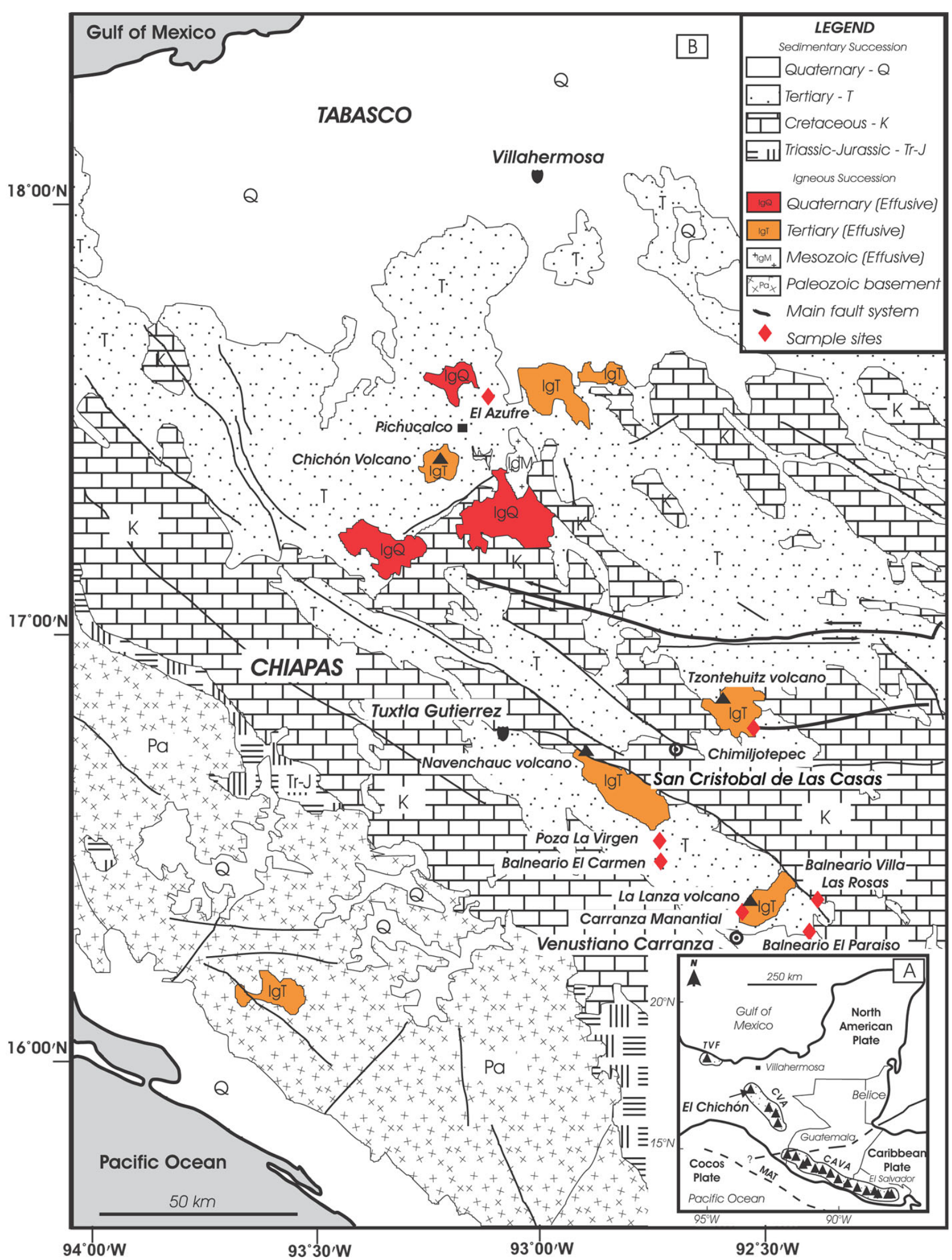

Fig. 1. A Sketch map of southern Mexico showing the location of the Chiapanecan Volcanic Arc (CVA), the Central America Volcanic Arc (CAVA), and Los Tuxtlas Volcanic Field (TVF). B Regional map of the Sierra de Chiapas region (modified after López-Ramos, 1979) and location of the water and gas discharge sampling sites. Note the location of springs and their vicinity to the Cenozoic volcanic centers of the CVA. 
1.39 $\times 10^{-6}$; Mamyrin and Tolstikhin, 1984) ratios in the gas phase were determined with a Map 215-50 magnetic mass spectrometer, equipped with an ion counting device. Resolution was close to $600 \mathrm{AMU}$ for $\mathrm{HD}-{ }^{3} \mathrm{He}$ at $5 \%$ of the peak. The $\mathrm{He} / \mathrm{Ne}$ ratio is measured with a quadrupole mass spectrometer (VG-Spectralab 200). Both the spectrometers are connected to a metal high-vacuum line, where gas samples are processed to separate noble gases from the gaseous matrix. The reproducibility of $\mathrm{R} / \mathrm{Ra}$ and $\mathrm{He} / \mathrm{Ne}$ ratios in air standard is better than $5 \%$ (Minissale et al., 2000; Magro et al., 2003).

\section{CHEMICAL COMPOSITION OF THE FLUID PHASES}

\subsection{Water chemistry}

Water samples have temperatures ranging between $11^{\circ} \mathrm{C}$ and $38.5^{\circ} \mathrm{C}$ and $\mathrm{pH}$ varying from slightly acidic (5.77) to slightly alkaline (7.61). The analytical results for the main components and some trace compounds are listed in Table 1. On the basis of both Total Dissolved Solids (TDS, Table 1) and relative abundance of $\mathrm{HCO}_{3}^{-}, \mathrm{SO}_{4}{ }^{2-}$ and $\mathrm{Cl}^{-}$ions (Figure 2), the Sierra de Chiapas waters can be divided, as follows: i) "Group I" (samples: Poza La Virgen, El Carmen I and II), that plots in the field pertaining to $\mathrm{Cl}^{-}$, with a $\mathrm{Na}-\mathrm{Cl}$ composition and TDS $>3000 \mathrm{mg} / \mathrm{L}$; ii) "Group II" (samples: Villa Las Rosas and El Paraiso), positioned close to the $\mathrm{SO}_{4}^{2-}$ corner, with a $\mathrm{Ca}-\mathrm{SO}_{4}$ composition and TDS values between 1400 and $2300 \mathrm{mg} / \mathrm{L}$; iii) "Group III" (samples: El Azufre Piscina I and II, El Azufre lake and El Carmen fria) with a
$\mathrm{Na}-\mathrm{Cl}$ composition and differing from "Group I" for having a lower salinity (TDS ranging from 800 to $2400 \mathrm{mg} / \mathrm{L}$ ) and a higher sulfate content (up to $650 \mathrm{mg} / \mathrm{L}$ ); iv) "Group IV" (samples: El Azufre fría, Villa Las Rosas fría, Cerro Tzontehuitz, Chimiljotepec, Carranza Manantial), close to the $\mathrm{HCO}_{3}^{-}$corner, characterized by a $\mathrm{Ca}-\mathrm{HCO}_{3}$ composition and low salinity (TDS $<250 \mathrm{mg} / \mathrm{L}$ ).

The strong positive correlation between $\mathrm{Na}^{+}$and $\mathrm{Cl}^{-}$(reported as meq/L) contents (Figure 3 ) in the Sierra de Chiapas waters suggests a common origin for these two ions and, possibly, resulting from the interaction with evaporitic material (dated lower Cretaceous-upper Jurassic by LópezRamos, 1979). As shown in Figure 4, with the only exception of waters pertaining to "Group IV", the $\left(\mathrm{Ca}^{2+}+\mathrm{Mg}^{2+}\right) /$ $\left(\mathrm{HCO}_{3}{ }^{2-}+\mathrm{SO}_{4}^{2}\right)$ ratios (as meq/L) are close to 1 , again suggesting that the contents of these chemical compounds are mainly related to dissolution processes of evaporitic material. $\mathrm{NH}_{4}^{+}$and $\mathrm{H}_{3} \mathrm{BO}_{3}$ contents show large variations (from 0.09 to $22 \mathrm{mg} / \mathrm{L}$ and from $<0.01$ and $16 \mathrm{mg} / \mathrm{L}$, respectively) and generally display a good correlation with $\mathrm{Cl}^{-}$contents and TDS (Table 1).

Nitrate contents vary between 0.11 and $4.5 \mathrm{mg} / \mathrm{L}$, with the exception of the Carranza spring, where anthropic pollution cannot be excluded. Bromide values (ranging from 0.01 to $2.2 \mathrm{mg} / \mathrm{L}$ ) show a positive correlation with $\mathrm{Cl}^{-}$contents (Figure 5). $\mathrm{F}^{-}$abundance goes from 0.02 to $1.8 \mathrm{mg} / \mathrm{L}$ while those of $\mathrm{Li}^{+}$vary from 0.02 to $0.66 \mathrm{mg} / \mathrm{L}$. $\mathrm{SiO}_{2}$ contents are between 11 to $31 \mathrm{mg} / \mathrm{L}$, showing clear correlation with the outlet temperatures. Silica concentrations of El Azufre springs, determined by using the heteropoly blue method,

\section{Table 1}

Chemical composition of mineral and cold waters of Sierra de Chiapas

\begin{tabular}{|c|c|c|c|c|c|c|c|c|c|c|c|c|c|c|c|c|c|c|c|c|c|}
\hline & Tipe & Date & $\mathbf{T}^{\circ} \mathbf{C}$ & pH & TDS & $\mathbf{N a}^{+}$ & $\mathbf{K}^{+}$ & $\mathbf{M g}^{2+}$ & $\mathrm{Ca}^{2+}$ & $\mathrm{NH}_{4}^{+}$ & $\mathbf{L i}^{+}$ & $\mathrm{SiO}_{2}$ & $\mathrm{CO}$ & ${ }_{3}^{-} \mathrm{Cl}^{-}$ & $\mathrm{SO}_{4}{ }^{2-}$ & $\mathrm{F}^{-}$ & $\mathrm{Br}^{-}$ & $\mathrm{NO}_{3}^{-}$ & $\varepsilon$ & $\delta^{18} \mathrm{O}$ & $\delta^{2} \mathbf{H}$ \\
\hline El A & tsg & nov 99 & 31.5 & 5.28 & 408 & 478 & 29 & 90 & 274 & 22 & 0.34 & n.a. & 720 & 842 & 621 & 1.0 & 1.9 & 0.11 & .98 & -4.5 & -21.0 \\
\hline $\mathrm{El} \mathrm{Az}$ & tsg & nov 99 & 31.3 & 6.5 & 2410 & 456 & 28 & 95 & 338 & 21 & 0.33 & n.a. & 701 & 760 & 650 & 1.1 & 1.8 & 0.12 & .29 & -4.3 & 20.0 \\
\hline El Azufre Natural & ts & nov 99 & 29 & 6.57 & 1573 & 284 & 19 & 62 & 230 & 15 & 0.22 & n.a. & 537 & 445 & 460 & 1.0 & 1.2 & 0.18 & 3.20 & n.a. & a. \\
\hline El Azufre fría & $\mathrm{s}$ & nov 99 & 23 & 7.56 & 148 & 5.4 & 1.2 & 19 & 53 & 0,08 & $<0.001$ & n.a. & 207 & 8.5 & 28 & 0.06 & 0.025 & 2.9 & 1.09 & -4.6 & -21.4 \\
\hline Tzontehuitz Volcano & $\mathrm{s}$ & nov 99 & 11 & 6.2 & 23 & 1.4 & 0.71 & 0.34 & 2.1 & 0,19 & $<0.001$ & 16 & 9.1 & 0.6 & 1.8 & 0.02 & $<0.01$ & $<$ & $<0.01$ & n.a. & n.a. \\
\hline Chim & $\mathrm{s}$ & nov 99 & 14 & 5.77 & 30 & 3.2 & 1.9 & 0.90 & 2.8 & 0,2 & $<0.001$ & 19 & 21 & 0.5 & 1.0 & 0.06 & 0.01 & 0.47 & $<0.01$ & n.a. & n.a. \\
\hline Las Rosas & tsg & nov 99 & 23.4 & 6.86 & 2286 & 1.7 & 2.0 & 131 & 525 & 3.4 & 0.04 & 18 & 287 & 2.7 & 1600 & 1.8 & 0.025 & 0.11 & $<0.01$ & -9.8 & -64.0 \\
\hline Bal. V. Las Rosas fria & $\mathrm{s}$ & nov 99 & 22 & 7.03 & 161 & 1.9 & 1.1 & 26 & 112 & 1.9 & $<0.001$ & 11 & 464 & 1.4 & 0.9 & 0.05 & $<0.01$ & 4.5 & $<0.01$ & -8.8 & -54.6 \\
\hline Bal. El Paraiso & ts & nov 99 & 25 & 7.51 & 1438 & 15 & 1.7 & 70 & 343 & 1.4 & 0.02 & 11 & 271 & 28 & 960 & 0.36 & 5 & 7.6 & $<0.01$ & -9.3 & -65.5 \\
\hline Carranza Manantial & $\mathrm{s}$ & nov 99 & 27 & 7.61 & 280 & 10 & 0.5 & 141 & 19 & 1.9 & $<0.001$ & 19 & 720 & 2.1 & 18 & 0.08 & $<0.01$ & 68 & 3.03 & n.a. & n.a. \\
\hline Bal. El Carmen I & tsg & nov 99 & 38.5 & 6.46 & 3092 & 855 & 72 & 61 & 255 & 1.6 & 0.66 & 24 & 744 & 1330 & 490 & 0.61 & 1.6 & 0.30 & $<0.01$ & -8.0 & -53.7 \\
\hline Bal El Carmen II & tsg & nov 99 & 38.5 & 6.55 & 3013 & 790 & 73 & 65 & 250 & 2.2 & 0.64 & 21 & 653 & 1300 & 505 & 0.68 & 2.2 & 1.8 & 5.43 & -8.3 & -55.3 \\
\hline Bal. El Carmen fría & ts & nov 99 & 30 & 6.7 & 874 & 180 & 17 & 32 & 141 & 3.6 & 0.15 & 20 & 367 & 265 & 210 & 0.18 & 0.40 & 4.2 & $<0.01$ & -8.3 & -53.6 \\
\hline Poza La Virgen & tsg & nov 99 & 37 & 6.44 & 3261 & 900 & 79 & 64 & 259 & 1.9 & 0.14 & 31 & 708 & 1410 & 510 & 0.51 & 1.5 & 0,33 & 16.01 & -8.4 & -56.3 \\
\hline
\end{tabular}

All the species are expressed in mg/L; TDS expressed in mg/L; n.a.=not analysed; tsg=thermal spring with gas associated; ts=thermal spring; $\mathrm{s}=$ cold spring. 


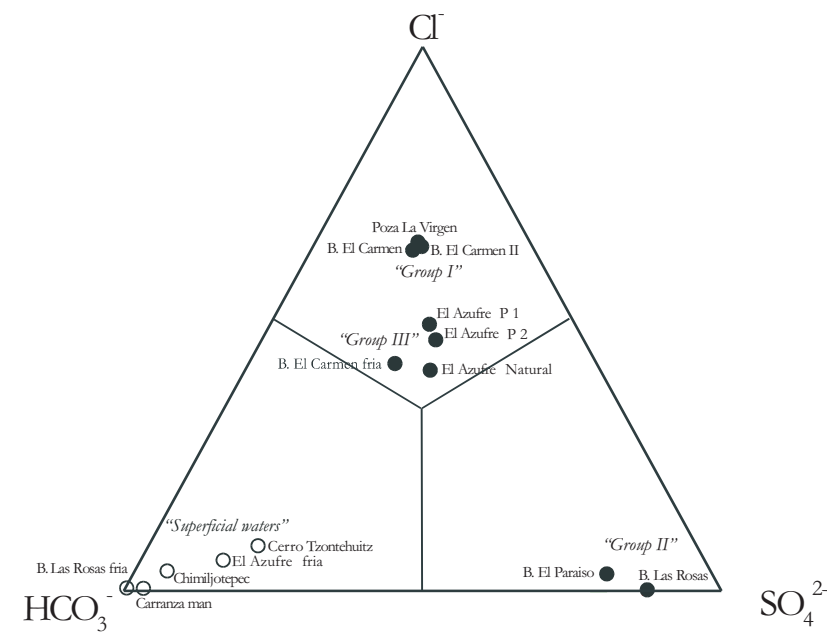

Fig. 2. $\mathrm{SO}_{4}^{2-}-\mathrm{Cl}^{-}-\mathrm{HCO}_{3}^{-}$ternary diagram for discharges from Sierra de Chiapas region. Open squares are cold springs $\left(\mathrm{T}<23^{\circ} \mathrm{C}\right)$; closed circles are: thermal springs $\left(\mathrm{T}>23^{\circ} \mathrm{C}\right)$.

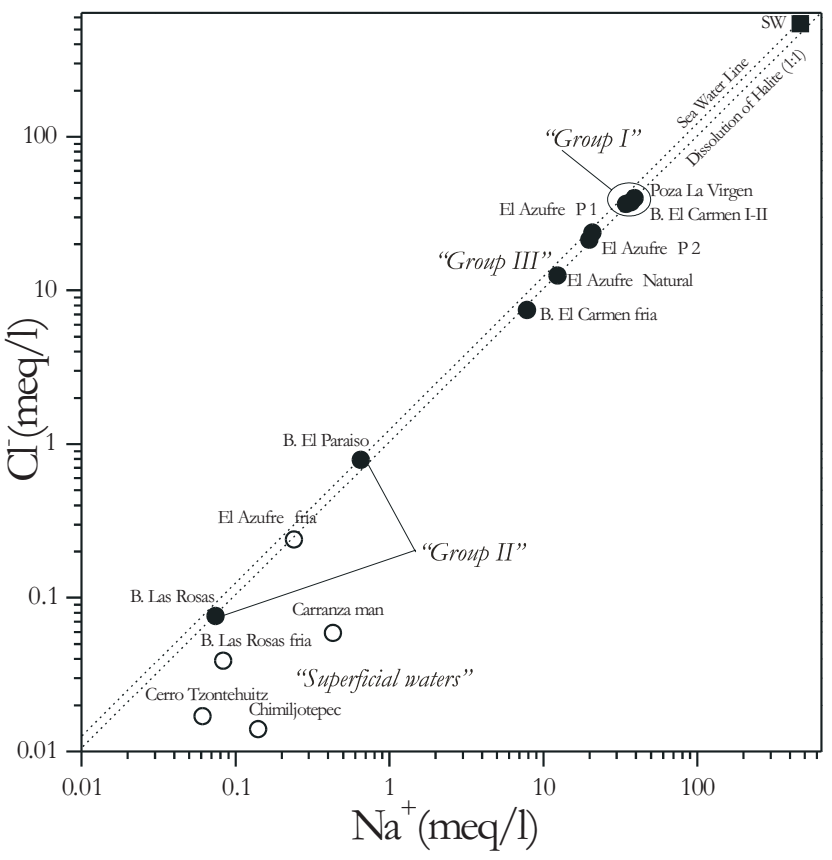

Fig. 3. $\mathrm{Na}^{+}$versus $\mathrm{Cl}^{-}$(in meq/L) diagram for water discharges from Sierra de Chiapas region. Ion contents are in $\mathrm{mg} / \mathrm{L}$. Symbols as in Fig. 2.

were up to $60 \mathrm{mg} / \mathrm{L}$. However, these values are jeopardized by the high $\mathrm{H}_{2} \mathrm{~S}$ contents (Table 2) and are not considered in the present work.

The $\mathrm{Na} / 400, \mathrm{~K} / 100$ and $\sqrt{\mathrm{Mg}}$ triangular diagram (Figure 6; Giggenbach, 1988) shows that all water samples fall within the immature water field and aligned along the waterrock dissolution line; thus, $\mathrm{K} / \mathrm{Na}$ and $\mathrm{K}^{2} / \mathrm{Mg}$ geothermometers can not be applied to obtain a real assessment of the reservoir equilibrium temperature. The silica geothermometers

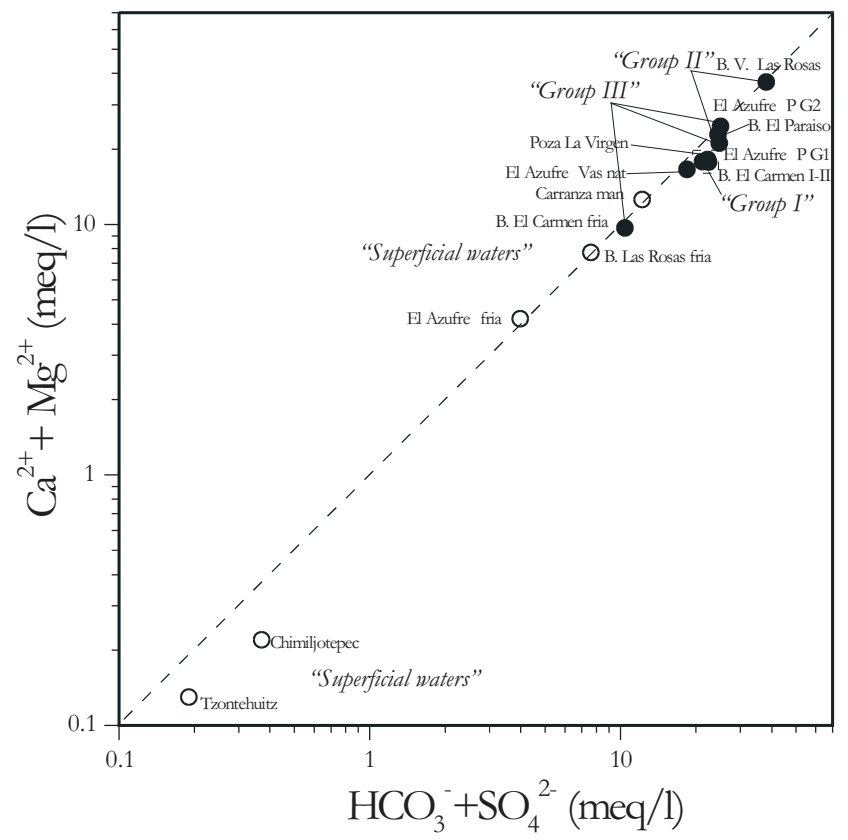

Fig. 4. $\mathrm{Ca}^{2+}+\mathrm{Mg}^{2+}$ vs. $\mathrm{HCO}_{3}+\mathrm{SO}_{4}{ }^{2-}$ diagram (in meq/L) for the water discharges from Sierra de Chiapas region. Symbols as in Fig. 2.

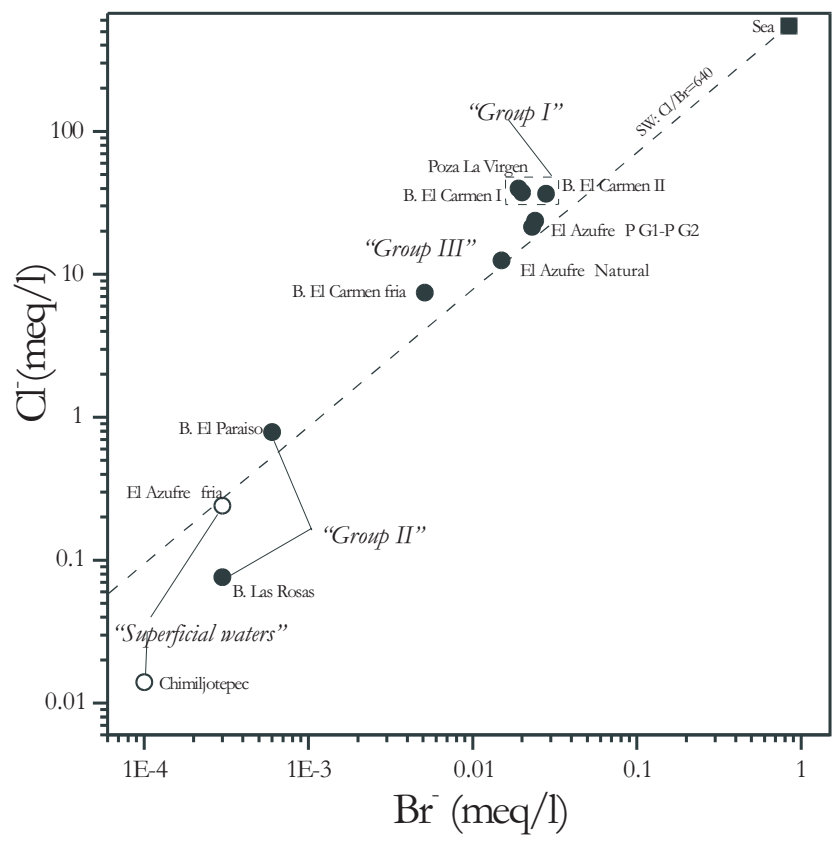

Fig. 5. $\mathrm{Br}^{-}$vs. $\mathrm{Cl}^{-}$diagram (in meq/L) for the water discharges from Sierra de Chiapas region.

used (Fournier and Rowe, 1966; Giggenbach and Corrales, 1988), applied to all the thermal waters but El Azufre, present more homogeneous values and range from $40{ }^{\circ} \mathrm{C}$ to $80{ }^{\circ} \mathrm{C}$, although these temperatures have to be regarded as minimum equilibrium temperatures due to the mixing processes between deep and superficial waters.

$\delta^{18} \mathrm{O}$ values vary between $-4.3 \%$ at El Azufre Piscina 
II and - $9.8 \%$ at Villa Las Rosas, whereas $\delta^{2} \mathrm{H}$ values range from -20.0\% SMOW at El Azufre Piscina II and -65.5\% at El Paraiso (Table 1). As shown in the binary diagram of Figure 7 , the $\delta^{18} \mathrm{O}-\delta^{2} \mathrm{H}$ values for all samples investigated approach the Global Meteoric Water Line (GMWL, Craig, 1963), suggesting that all the water discharges have a meteoric origin.

\subsection{Gas chemistry}

The chemical composition (in \% by vol.) of gas samples is reported in Table 2. $\mathrm{N}_{2}$ is always the main component (up to $93 \%$ ), while $\mathrm{CO}_{2}$ content varies from $2.4 \%$ to $31.2 \% . \mathrm{O}_{2}$ contents are very low or under the detection limit $(0.001 \%)$, while high contents of Ar, larger than the concentration in air $(0.93 \%)$, have been measured in all samples (up to $1.25 \%$ ). $\mathrm{H}_{2} \mathrm{~S}$ is present in detectable amounts $(>0.005 \%)$ only in the gas samples collected at El Azufre (up to $1.1 \%$ ).

Among hydrocarbons, $\mathrm{CH}_{4}$ is the most abundant component (up to $5.0 \%$ in vol.), but significant amounts of ethane, propane, $i$-butane, $l$-butene and $i$-butene have also been detected (up to $1.2 \%$ of the total organic compound contents) (Table 2). He contents are of the order of some hundreds of ppm by vol., while $\mathrm{H}_{2}$ and Ne contents are from 2 to 20 and from 5.4 to 9.5 ppm by vol., respectively. $\mathrm{CO}$ is always below the instrumental detection limit $(<0.1 \mathrm{ppm}$ by vol).

In the $10 \mathrm{He}-\mathrm{N}_{2} / 100$-Ar ternary diagram (Figure 8) all gas samples plot in the field defined by air, ASW (Air-Saturated Water, Giggenbach et al., 1983) and the He corner, indicating that $\mathrm{N}_{2}$ and Ar are mostly atmospheric-originated, while considerable amounts of non-atmospheric He (with values up to 363 ppmv, Table 2) were added to the circulating fluids.

$\mathrm{R} / \mathrm{Ra}$ values (Table 2) range between 0.6 at El Azufre

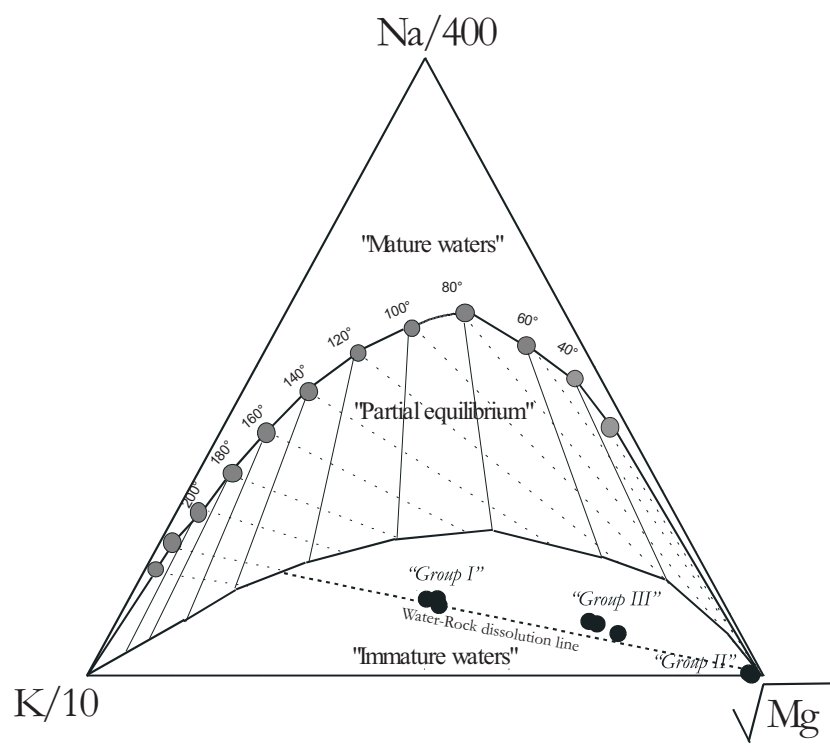

Fig. 6. Triangular diagram of $\mathrm{Na} / 400-\mathrm{K} / 10-\sqrt{\mathrm{Mg}}$ (Giggenbach and Corrales, 1992).

Piscina I sample and 1.0 at El Carmen sample, which may indicate, if we consider a value of $\mathrm{R} / \mathrm{Ra}=8$ for the a MORBtype mantle (Martel et al., 1989; Ozima et al., 2002), a contribution of $7-13 \%$ of mantle-derived ${ }^{3} \mathrm{He}$. The $\delta^{13} \mathrm{C}$ in $\mathrm{CO}_{2}$ values (Table 2) range between $-9.7 \%$ to $-12.5 \%$ PDB. These isotopic values seem to be in relation with decomposition of organic material (up to $\delta^{13} \mathrm{C}=-20 \%$ PDB), although mixing with a deeper-originated (mantle- or thermometamorphic-related) end-member (possibly characterized by $\left.-7<\delta^{13} \mathrm{C}<+1\right)$ cannot be excluded.

\section{DISCUSSION AND CONCLUSIONS}

The chemical and isotopic data of sampled water and gas discharges in the Sierra de Chiapas, Mexico may give some insights on the origin and on the chemical evolution of

Table 2

Chemical composition of gas discharges from Sierra de Chiapas

\begin{tabular}{|c|c|c|c|c|c|c|c|c|c|c|c|c|c|c|c|c|c|c|}
\hline & Date & $\mathrm{CO}_{2}$ & $\mathbf{N}_{2}$ & $\mathbf{H}_{2} \mathrm{~S}$ & Ar & $\mathbf{O}_{2}$ & $\mathrm{CH}_{4}$ & He & $\mathbf{H}_{2}$ & $\mathrm{Ne}$ & $\mathrm{CO}$ & Etane & Propane & i-Butane & 1-Butene & i-Butene & $\delta^{13} \mathrm{C}-\mathrm{CO}_{2}$ & $\mathbf{R} / \mathbf{R}_{\mathrm{A}}$ \\
\hline El Azufre P 1 & nov 99 & 18.24 & 79.0 & 0.82 & 1.10 & 0.005 & 1.10 & 162 & 13.20 & 8.7 & $<0.01$ & 83 & 1.2 & 0.27 & 0.18 & 0.09 & -10.5 & 0.57 \\
\hline El Azufre P 1a & nov 99 & 18.21 & 79.0 & 0.86 & 1.03 & 0.005 & 1.11 & 263 & 15.60 & 7.8 & $<0.01$ & 133 & 2.0 & 0.62 & 0.09 & 0.31 & -9.7 & \\
\hline El Azufre P 2 & nov 99 & 29.25 & 68.0 & 0.55 & 0.99 & 0.014 & 0.95 & 208 & 53.00 & 7.7 & $<0.01$ & 115 & 1.6 & 0.40 & 0.04 & 0.08 & -12.3 & \\
\hline El Azufre lake & nov 99 & 2.39 & 93.0 & 1.10 & 1.21 & 0.330 & 1.59 & 274 & 8.66 & 9.4 & $<0.01$ & 156 & 2.3 & 0.73 & 0.05 & 0.11 & -11.3 & \\
\hline Bal. El Carmen & nov 99 & 30.70 & 63.0 & $<0.01$ & 0.85 & 0.570 & 5.04 & 363 & 5.42 & 5.7 & $<0.01$ & 5.8 & & & & & 9.7 & 1.03 \\
\hline $\begin{array}{l}\text { Poza la Virgen } \\
\text { Bal Villa }\end{array}$ & nov 99 & 31.17 & 53.0 & $<0.01$ & 0.74 & 11.000 & 4.57 & 249 & 20.70 & 5.4 & $<0.01$ & 14 & & & & 0.92 & 9.7 & 1.03 \\
\hline Las Rosas & nov 99 & 3.01 & 95.0 & $<0.01$ & 1.25 & 0.730 & 0.03 & 15.5 & 2.00 & 9.5 & $<0.01$ & 1.0 & & & & 0.11 & 12.5 & 0.66 \\
\hline
\end{tabular}

All data are in $\%$ by volume, with the exception of $\mathrm{He}, \mathrm{H}_{2}, \mathrm{Ne}, \mathrm{Co}$, Etane, Propane, i Butane, l-Butane, i-Butene that are in ppmv. 


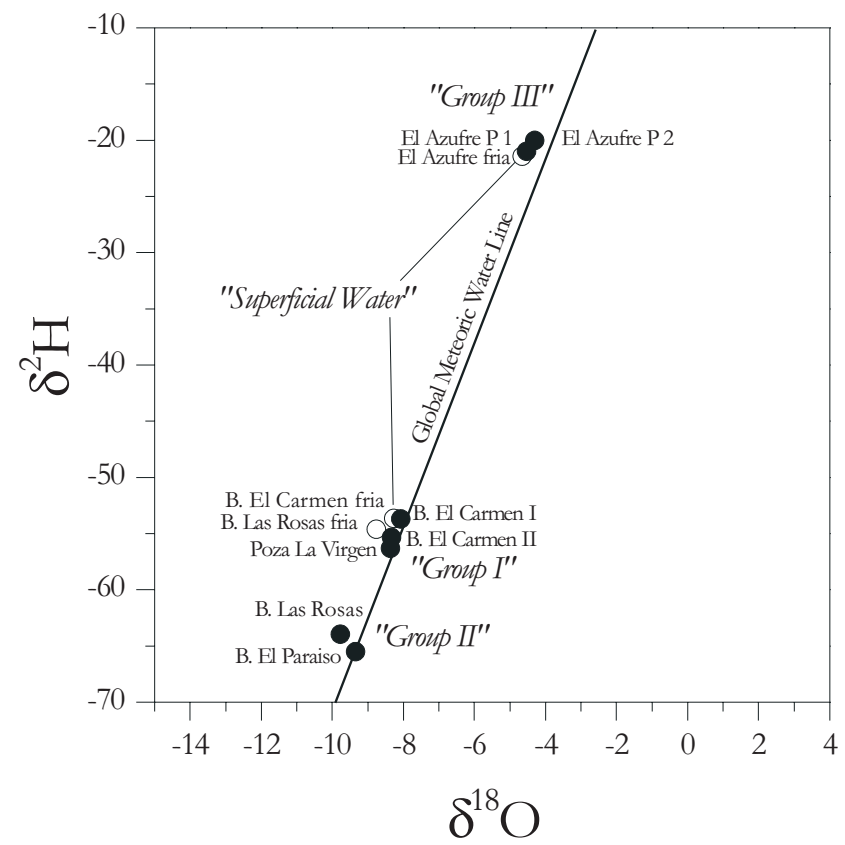

Fig. 7. $\delta^{18} \mathrm{O}-\delta D$ diagram for water discharges from Sierra de Chiapas region. The Global Meteoric Water Line (after Craig, 1963) is reported.

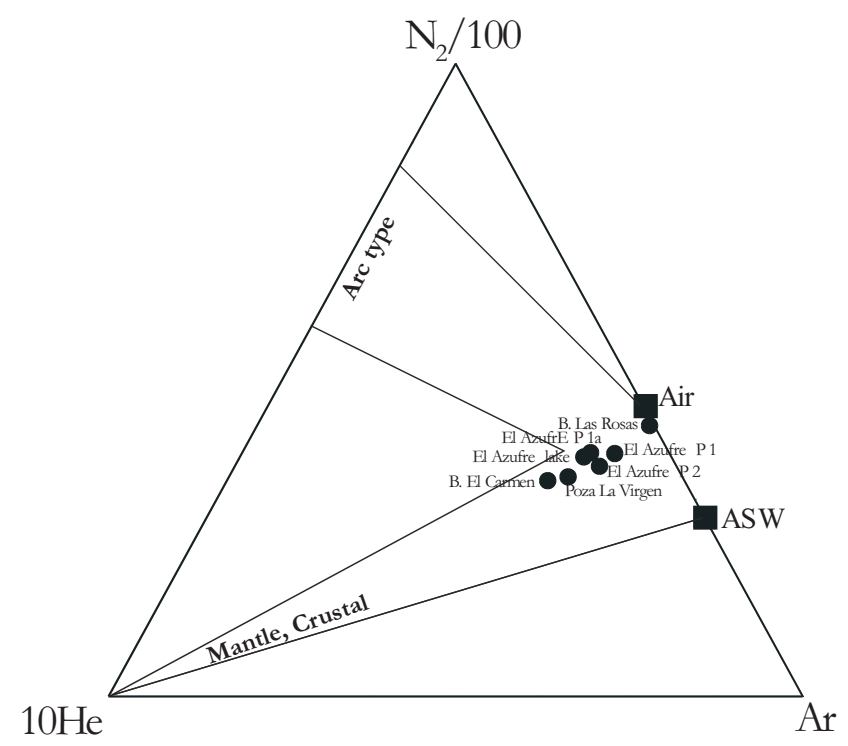

Fig. 8. $\mathrm{N}_{2} / 100$-Ar-He*10 ternary diagram for gas discharges from Sierra de Chiapas region (after Giggenbach, 1993).

the thermal fluids in the region. The TDS values are plotted versus the percentage of $\mathrm{HCO}_{3}^{-}$with respect to the sum of total anions $\left(\mathrm{HCO}_{3}+\mathrm{SO}_{4}{ }^{2-}+\mathrm{Cl}^{-}\right)$and reported in Figure 9. It can be speculated that water chemistry may be related to mixing processes between a superficial aquifer, represented by the cold spring discharges ("Group IV" samples), and a more saline end member, characterized by a composition similar to that of both Poza La Virgen and Balneario El Carmen I and II waters ("Group I" samples). The striking correspondence between the location of the thermal springs and the outcrops of the Cenozoic volcanic rocks (Figure 1) suggests that fluid circulation is controlled by the main fracture and fault systems (Nencetti 2001).

The predominance of atmospheric-related components in all gas phases sampled (Table 2) and the $\delta^{18} \mathrm{O}$ and $\delta^{2} \mathrm{H}$ values of all spring samples (Table 1; Figure 5) suggests that the presence of active high enthalpy hydrothermal systems at relatively shallow depths seems unlikely. This is in accordance with recent investigations on the geothermal resources of Chiapas (Prol Ledesma and Juárez, 1986), which indicate deep fluid temperatures ranging from $85^{\circ} \mathrm{C}$ to $110^{\circ} \mathrm{C}$. Chemi$\mathrm{cal}$ and isotopic considerations may allow to hypothesize a possible scheme for the evolution of the circulating fluids. Meteoric waters easily infiltrate through the south-east oriented outcrops of upper and middle-Cretaceous carbonate units, which extend from Tuxtla Gutiérrez and Venustiano Carranza up to Pichucalco (Figure 1). The permeability of these rocks is possibly enhanced by the fault systems related to the regional tectonics (López-Ramos, 1979; Canul and Rocha, 1982; Nixon, 1982; Macías et al., 1997; Meneses Rocha, 1991; García-Palomo et al., 2004). The typical atmospheric gases such as $\mathrm{N}_{2}, \mathrm{O}_{2}, \mathrm{Ar}$ and $\mathrm{Ne}$ enrich the groundwater during the infiltration process, as dissolved gas species in the rainfall water. Therefore, permeated meteoric waters reach the evaporitic rocks (i.e. anhydrite halitecarbonatic formation) that are located at variable depth (Montes de Oca, 1979; López Ramos, 1979; Duffield et al., 1984). During the circulation, prolonged water-rock interactions occur and the temperature of the waters tend to increase as they deepen. Contemporaneously, $\mathrm{CO}_{2}$, possibly also deriving from deep sources (mantle- and/or thermometamorphicderived), and He deriving from radiogenic decay in the crustal environment, are produced and added to these thermal fluids. However, as indicated by R/Ra values of Poza La Virgen and El Carmen II gas discharges, which emergence locations are in coincidence with the presence of igneous bodies of upper Pleistocene age (Figure 1), some contribution of mantellic ${ }^{3} \mathrm{He}$, related to the active tectonic regime of the area, cannot be excluded. Moreover, at shallow level, during the ascending phase of the convective circuit, some isotopically light $\mathrm{CO}_{2}$, derived from the alteration of organic matter (as supported by the $\delta^{13} \mathrm{C}$ values), $\mathrm{H}_{2} \mathrm{~S}$ and hydrocarbon compounds further modify the chemical characteristics of the gas thermal discharges. In conclusion, the chemical and isotopic characteristics of the Sierra de Chiapas gas and water discharges, suggest that the presence of active high enthalpy hydrothermal systems at relatively shallow depths seems to be unlikely.

\section{ACKNOWLEDGEMENTS}

This study was supported by a CNR-CONACYT Bilateral Project and by the Italian Space Agency (ASI, Resp. $\mathrm{OV})$. Many thanks are due to M. Paolieri for his assistance 


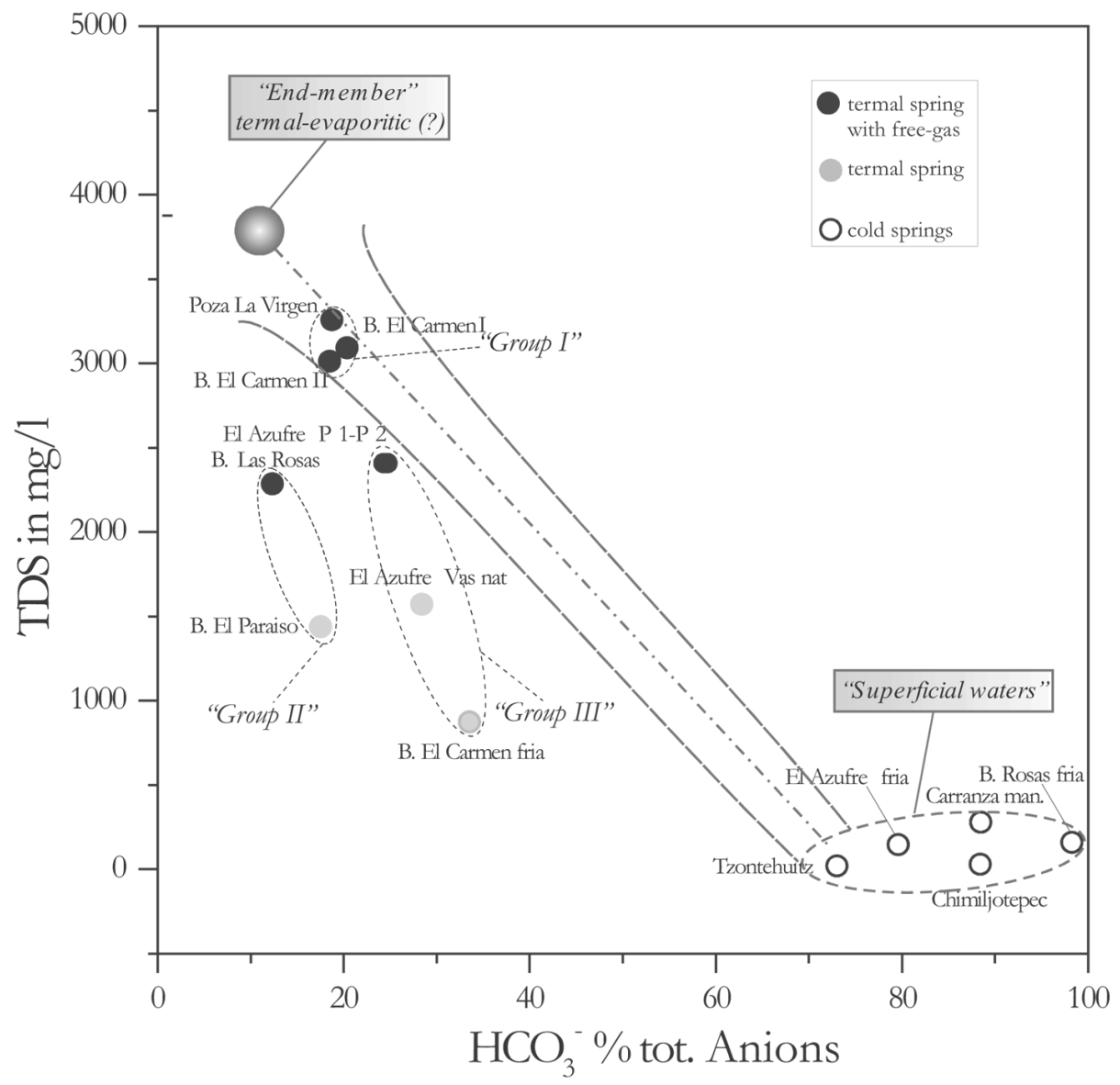

Fig. 9. TDS (in ppm) and $\mathrm{HCO}_{3}^{-}$(in \% with respect to the sum of $\mathrm{HCO}_{3}^{-}, \mathrm{SO}_{4}{ }^{2-}$ and $\mathrm{Cl}^{-}$) for the water discharges from Sierra de Chiapas region. Symbols as in Fig. 2.

during the stable isotopic analysis. Yuri Taran and an anonymous reviewer are warmly thanked for their criticism and suggestions.

\section{BIBLIOGRAPHY}

BURBACH, V. G., C. FROHLICH, D. W. PENNINGTON and T. MATUMOTO, 1984. Seismicity and tectonics of the subducted Cocos Plate. J. Geophys. Res., 89 , 77197735 .

CANUL, R. F. and V. L. ROCHA, 1982. Informe geológico de la zona geotérmica de "El Chichónal", Chiapas. Unpublished Report Comisión Federal De Electricidad, Morelia, Michoacán, México, 38p.

CAPAUL, W. A., 1987. Volcanoes of the Chiapas volcanic belt, Mexico. Thesis. Michigan Tecnological University, pp 93.

CAPACCIONI, B., Y. TARAN, F. TASSI, O. VASELLI, F. MANGANI and J. L. MACÍAS, 2004. Source conditions and degradation processes of light hydrocarbons in volcanic gases: an example from El Chichón volcano (Chiapas State, Mexico). Chem. Geol., 206, 81-96.

CRAIG, H., 1963. Isotopic variations in meteoric waters. Science, 123, 1702-1703.

DAMON, P. E. and E. MONTESINOS, 1978. Late Cenozoic volcanism and metallogenesis over an active Benioff zone in Chiapas, Mexico. Arizona Geol. Soc. Digest, 11, 155-168.

DE LA ROSA, J. L., A. EBOLI and M. DÁVILA, 1989. Geología del Estado de Chiapas. Subdirección de Construcción, Comisión Federal de Electricidad. Harla, Mexico City, 192 p.

DUFFIELD, W. A., R. I. TILLING and R. CANUL, 1984. Geology of El Chichón Volcano, Chiapas, Mexico. J. Volcanol. Geotherm. Res., 20, 117-132.

FERRUSQUIA-VILLAFRANCA, I., 1996. Contribución al conocimiento geológico de Chiapas-El área de Ixtapa- 
Soyaló. Boletín 109, Instituto de Geología, UNAM, 130 p.

FOURNIER, R. O. and J. J. ROWE, 1966. Estimation of underground temperatures from the silica content of water from hot spring and wet-steam wells. Am. Jour. Scie., 264, 685-697.

GARCÍA-PALOMO, A., J. L. MACÍAS and J. M. ESPÍNDOLA, 2004. Strike-slip faults and K-Alkaline volcanism at El Chichón volcano, southeastern Mexico. J. Volcanol. Geotherm. Res., 136, 247-268.

GIGGENBACH, W. F., 1975. A simple method for the collection and analyses of volcanic gas sample. Bull. Volcanol., 39, 132-145.

GIGGENBACH, W. F., 1988. Geothermal solute equilibria. Derivation of Na-K-Mg-Ca geoindicators. Geoch. Cosmoch. Acta, 52, 2749-2765.

GIGGENBACH, W. F. and R. CORRALES, 1992. Isotopic and chemical composition of water and steam discharges from volcanic-magmatic-hydrothermal system of the Guanacaste Geothermal Province, Costa Rica. Appl. Geochem., 7, 309-322.

GIGGENBACH, W. F., R. GONFIANTINI, B. L. JANGI and A. H. TRUESDELL, 1983. Isotopic and chemical composition of Parbaty valley geothermal discharges, NW-Himalaya. Geotherm., 12, 199-222.

HAVSKOV, J., S. DE LA CRUZ-REYNA, S. SINGH, F. MEDINA and C. GUTIÉRREZ, 1983. Seismic activity related to the March-April, 1982 eruptions of El Chichón volcano, Chiapas, Mexico. Geophys. Res. Let., 10, 293296.

LÓPEZ-RAMOS, E. L., 1979. Geología de México. Edición Escolar, Tomo III, segunda edición, México, D.F., México, 446 pp.

LUHR, J. F., I. S. E. CARMICHAEL and J. C. VAREKAMP, 1984. The 1982 eruptions of El Chichón Volcano, Chiapas, Mexico: mineralogy and petrology of the anhydrite-bearing pumices. J. Volcanol. Geotherm. Res., 23, 69-108.

MACÍAS, J. L., J. M. ESPÍNDOLA, Y. TARAN and P. A. GARCÍA, 1997. Explosive volcanic activity during the last 3,500 years at el Chichon volcano, Mexico. IAVCEI, General Assembly, Puerto Vallarta, Mexico. Field trip guide, $53 \mathrm{p}$.
MACÍAS, J. L., J. L. ARCE, J. C. MORA, J. M. ESPÍNDOLA, R. SAUCEDO and P. MANETTI, 2003. The 550 BP plinian eruption of el Chichon volcano, Chiapas, Mexico: Explosive volcanism linked to reheating of a magma chamber. J. Geophys. Res., 108(b12), 2569.

MAGRO, G., G. RUGGIERI, G. GIANELLI, S. BELLANI and G. SCANDIFFIO, 2003, Helium isotopes in paleofluids and present-day fluids of the Larderello geothermal field: Constraints on the heat source. J. Geophys. Res., 108(B9), doi: 10.1029-/2001JB001590, 2003.

MARTEL, D. J., J. DEAK, P. DOVENYI, F. HORVATH, R. K. O'NIONS, E. R. OXBURGH, L. STEGENA and M. STUTE, 1989. Leakage of helium from pannonian basin. Nature, 342, 908-912.

MAMYRIN, B. A. and I. N. TOLSTIKHIN, 1984. Helium isotopes in natura. In: Fyfe, W.S. (Ed), Developments in Geochemistry, Series 3, Elsevier, Amsterdam.

MENESES-ROCHA, J. J., 1991. Tectonic Development of the Ixtapa Graben, Chiapas, Mexico. Ph. D., University of Texas, Austin, 308 pp.

MINISSALE, A., G. MAGRO, G. MARTINELLI, O. VASELLI and F. TASSI, 2000. Fluid geochemical transect in the Northen apennines(central-northern Italy): fluid genesis and migration and tectonic implications. Tectonophysics, 319, 199-222.

MONTES DE OCA, S., 1979. Geología petrolera de la Sierra de Chiapas. Asoc. Mex. Geol. Pétrol., Bol., 31 (12), 67-97.

MUGICA, R., 1987, Estudio petrogenético de las rocas ígneas y metamórficas en el Macizo de Chiapas: Instituto Mexicano del Petróleo, C-2009.

NENCETTI, A., 2001. Geochimica dei fluidi del Vulcano El Chichón (Chiapas, Messico). Unpublished Ms Thesis, University of Florence (Italy), pp 181. (In Italian).

NIXON, G. T., 1982. The relationship between Quaternary volcanism and the seismic structure of subducted ocean litosphere. Bull. Geoc. Soc. Am., 93, 514-523.

OZIMA, M. and F. A. PODOSEK, 2002. Noble gas geochemistry. Cambridge University Press, Second Edition, 286 pp. 
PROL-LEDESMA, R. M. and M. G. JUÁREZ, 1986. Geothermal map of Mexico. J. Volcanol. Geotherm. Res., 28, 351-362.

ROUWET, D., Y. A. TARAN and N. R. VARLEY, 2004. Dynamics and mass balance of El Chichón crater lake, Mexico. Geofís. Int., 43, 427-434.

TARAN, Y., T. P. FISCHER, B. POKROVSKY, Y. SANO, M. A. ARMIENTA and J. L. MACÍAS, 1998. Geochemistry of the volcano-hydrothermal system of El Chichón Volcano, Chiapas, Mexico. Bull. Volcanol., 59, 436-449.

TASSI, F., O. VASELLI, B. CAPACCIONI, J. L. MACÍAS, A. NENCETTI, G. MONTEGROSSI and G. MAGRO, 2003. Chemical composition of fumarolic gas and spring discharges from El Chichón volcano, Mexico: causes and implications of the changes detected over the period 1998-2000. J. Volcanol. Geotherm. Res., 123, 105121.

XU, S., S. NAKAI, H. WAKITA, X. WANG and X. FENG, 1997. Effects of hydrothermal processes on the chemi- cal and isotopic composition of mantle-derived gases in SE China. Pergamon, Geothermics, 26, 2, 179-192.

A. Nencetti ${ }^{1}$, F. Tassi ${ }^{1}$, O. Vaselli ${ }^{1,2, *}$, J. L., Macías ${ }^{3}$, G. Magro ${ }^{4}$, B. Capaccioni ${ }^{5}$, A. Minissale ${ }^{2}$, J. C. Mora $^{3}$

${ }^{1}$ Department of Earth Sciences, Via G. La Pira 4, 50121 Florence, Italy

${ }^{2}$ CNR-Institute of Geosciences \& Earth Resources, Via G. La Pira 4, 50121 Florence (Italy)

${ }^{3}$ Institute of Geophysics, UNAM, D.F., 04510 Mexico City (Mexico)

${ }^{4}$ CNR-Institute of Geosciences \& Earth Resources, Via G. Moruzzi 1, 56124 Pisa (Italy)

${ }^{5}$ Institute of Vwolcanology and Geochemistry, Loc. La Crocicchia, Ex-Sogesta 61029 Urbino (Italy)

* Corresponding author: Orlando Vaselli, Department of Earth Sciences, Via G. La Pira, 4 - 50121 Florence (Italy). Tel: +39055 2756289; Fax: +39055 284571;

Email:orlando@geo.unifi.it 